\section{Mirjana Jokanović ${ }^{1}$ Aleksandra Koprivica}

\title{
THE IMPACT OF THE SERVICE PROVIDER AND THE SERVICE RECIPIENT ON THE QUALITY OF THE SERVICE IN DIFFERENT SERVICE SYSTEMS
}

\begin{abstract}
The goal of each service process should be an excellent service that satisfies the user and meets the strategic goals of the company. It is usually the result of careful design and delivery of a whole set of interconnected processes, subprocesses, operations, or activities.

When it comes to processes, it's not just about the part where the user receives the service. Service providers consistently meet customer expectations, manage the chain of processes from the beginning to the end, whose last link is providing service to the user.

In this paper, a systematic overview of literature was given, where, as the criteria, when selecting papers from the field that was the subject of research, were: time distance, i.e. the papers in the past five years have been analyzed, as well as the main actors in the service process and their impact on the level of quality of the service provided - the provider and the recipient of the service.
\end{abstract}

Keywords: quality, service, service provider, serive recipient

\section{Introduction}

The product represents the way in which the company aligns its capabilities, on the one hand, with the needs, demands and expectations of users, on the other hand, because in fact, the user's needs do not exist because of the product, but the product exists because of user needs.

Under the product, everything that can be sold is implied, whether it's goods, services, ideas, or any combination of those terms. It is precisely on the basis of the previous division that all enterprises can be classified into production (those that are oriented towards the production of goods) and service (those that provide services).

The service is understood as any action or performance that one party can offer to another and is result from the application of human and mechanical efforts to persons and objects.

\section{Services and service processes}

Some of the major differences between goods and services are given in the following table 1 .

A good service process ensures that the service is provided consistently. The designed service is provided by the prescribed procedures that will follow in

\footnotetext{
${ }^{1}$ Corresponding author: Mirjana Jokanović Email: mirjana.jokanovic@fpm.ues.rs.ba
} 
providing the service. The procedures define how other necessary resources will be used (equipment, material, etc.) in order to provide the desired service [2].

Table 1. Differences between goods and services [1]

\begin{tabular}{|c|c|}
\hline GOODS & SERVICES \\
\hline Tensile. & Incompatible. \\
\hline Production companies. & $\begin{array}{c}\text { Service companies - } \\
\text { organizations. }\end{array}$ \\
\hline $\begin{array}{l}\text { Time gap between } \\
\text { production and use. }\end{array}$ & $\begin{array}{l}\text { Simultaneous } \\
\text { provision and } \\
\text { consumption. }\end{array}$ \\
\hline $\begin{array}{l}\text { The place of origin of } \\
\text { goods is usually } \\
\text { physically distant from } \\
\text { the consumer. }\end{array}$ & $\begin{array}{l}\text { A means of } \\
\text { providing a service } \\
\text { close to the } \\
\text { consumer. }\end{array}$ \\
\hline $\begin{array}{l}\text { The possibility of a high } \\
\text { degree of automation of } \\
\text { the production process. }\end{array}$ & $\begin{array}{c}\text { It requires a } \\
\text { significant share of } \\
\text { manual and } \\
\text { thoughtful work. }\end{array}$ \\
\hline $\begin{array}{l}\text { Accurately defined } \\
\text { procedures for } \\
\text { measuring qualitative } \\
\text { characteristics. }\end{array}$ & $\begin{array}{l}\text { Determining } \\
\text { qualitative } \\
\text { characteristics is } \\
\text { quite difficult. }\end{array}$ \\
\hline $\begin{array}{l}\text { Quality is not in the } \\
\text { function of an } \\
\text { individual who } \\
\text { produces goods. }\end{array}$ & $\begin{array}{c}\text { The quality of } \\
\text { service provision } \\
\text { depends to a large } \\
\text { extent on the service } \\
\text { provider. }\end{array}$ \\
\hline $\begin{array}{l}\text { Output is precisely } \\
\text { defined. }\end{array}$ & $\begin{array}{l}\text { The result of } \\
\text { providing a service } \\
\text { is difficult to } \\
\text { quantify. }\end{array}$ \\
\hline $\begin{array}{l}\text { Value remains } \\
\text { preserved for a longer } \\
\text { period of time. }\end{array}$ & $\begin{array}{l}\text { Value changes } \\
\text { rapidly, most often } \\
\text { decreases. }\end{array}$ \\
\hline Mass. & Unique. \\
\hline $\begin{array}{l}\text { No direct contact } \\
\text { between consumers and } \\
\text { the manufacturer. }\end{array}$ & $\begin{array}{l}\text { Direct contact } \\
\text { between the service } \\
\text { provider and the } \\
\text { consumer is } \\
\text { necessary. }\end{array}$ \\
\hline
\end{tabular}

The goal of each service process should be an excellent service that satisfies the user and meets the strategic goals of the company. Usually represents the result of careful design and delivery of a whole set of interconnected processes, subprocesses, operations, or activities [2].
When it comes to processes, it's not just about the part where the user receives the service. Service providers consistently meet customer expectations, manage the chain of processes from the beginning to the end, whose last link is providing service to the user. Also, it is important to emphasize that services often fail because they are not adequately designed and executed [2]. A simplified service process is shown in Figure 2.

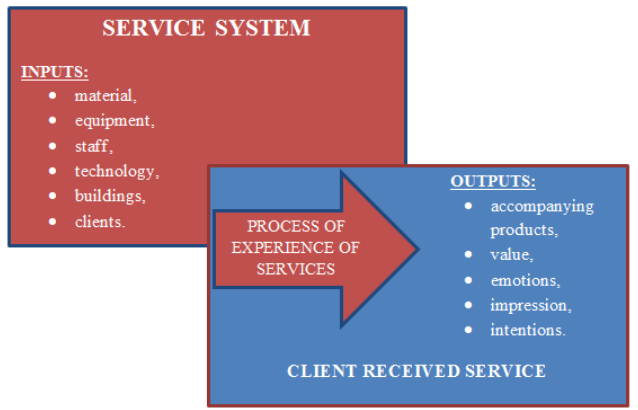

Figure 1. Simplified service process [2]

\section{Overview of the research in the field of the service systems}

This chapter is based on the analysis of scientific papers, authors who have been studying the field of service systems, with an accent on the quality of these.

The word quality comes from the Latin word qualitas, which means property, character, virtue, value. It is a concept of a broad meaning, which itself pertains to something good and is one of the most important characteristics of the product [2].

There are different perceptions of quality by customers and manufacturers. It is important for the buyer that the product meets his wishes and it can, of course, be said to be subjective, and aims to achieve satisfaction of the product, when used or consumed.

On the other hand, the quality of the manufacturer means that the product is made according to specifications, that is, according to the project documentation.

In doing so, it is important to note the 


\section{Intermationall Qualilty Conference 13}

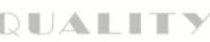
IRIFSIFAIDCII

demands of buyers and producers, where customers want to get as good quality as possible for as little as possible money, while manufacturers seek to maximize production costs, to achieve the desired quality.

In his work, the authors Mladen Knežević et al. (2015) engaged in research aimed at demonstrating whether there is a correlation between the physical appearance of visitors and beneficiaries of hotel and social service centers and the quality of services provided to employees by the previous ones. The survey shows that there is indeed a positive correlation between the physical appearance of the hotel visitors and their satisfaction with the quality of services received. On the other hand, within the group of social workers and their clients, there was no correlation between the client's physical appearance and satisfaction with the service provided.

In their research, Bekir Bora Dedeoglu and Halil Demirer (2015) point out that employees generally consider that the quality of their services is higher than the clients think, where they analyzed the roles of the stakeholders in the organization, customers, managers and employees, as well as their impact on the quality of the service provided. Authors emphasize that if customers are satisfied with the quality of the services provided, they will choose that organization again, and also with positive comments will promote the organization to the general public, which is certainly one of the benefits for service providers.

Juan de Onja and Rosio de Onja (2014), in their research, related to the quality of public transport services, summarized the evolution of research and thinking at that time, in relation to different methodological approaches, to evaluate the quality of service in public transport over the years. In their work they outline the basic characteristics of the quality of services in the transport sector: the complexity of the concept of quality, attributes of service quality, nature of data, and surveys, as well as the methods used for modeling, when analyzing quality.

The quality of service and productivity in the airline industry in the US countries, is a title of the survey, conducted by Kanghwa Choi et al. (2013). The authors believe that, although there were short-term compromises between service quality and productivity, in the long run, the focus on quality of services can help improve customer satisfaction, thereby improving productivity of services and overall organizational performance.

The quality of services and training of the topic was dealt with by Rahib Lohan Dhar (2014). The paper showed that there is a strong link between employee training and the quality of service provided. It has also been shown that commitment was a great mediator between the two aforementioned terms. The paper emphasized that tourist hotels, which operate as small and medium enterprises, have to be trained to improve their performance. The author said that, if the company wants to achieve a viable competitive advantage, it is important to implement sustainable employee development practices through the acquisition of new skills and upgrading, which is considered the most effective way to improve efficiency in the SME sector.

Relations between the satisfaction of rail passengers and the efficiency of service quality, with emphasis on the identification of key factors of services, is the name of the work of the authors Laura Eboli and Gabriele Mazule (2014). After the research was carried out, the authors found that macro factors in terms of information, cleanliness and services have the highest positive effect on the overall quality of service.

Domestic, in relation to foreign service providers, with an emphasis on the impact of the cost, time and quality of the victim on the choice of consumers, is the research which was done by Andrej M. Forman et al. (2015). The results support the idea that while consumers significantly prefer 
domestic, rather than foreign service providers, providers are not willing to accept a monetary or time-sacrifice to allow them access. In conclusion, the authors emphasize that, on an equal footing, consumers tend to be "service ethnocentric".

Role of fairness of service in quality of service - quality of relationships - customer loyalty chain, is the title of the paper, authored by Apostolos Đovanis et al. (2015). This research is corroborated by some earlier research that asserts that fairness and quality of service are determinants of service user ratings and they, to a large extent, determine the quality of relationships between service providers and clients. In conclusion, the authors state that clients who experience a higher level of quality of service and feel that they have been treated in a fair way by the service provider are likely to develop a better relationship with the service provider and remain loyal to the organization.

Racial disorder and emotional work are areas of research that were studied by Allysia $S$. Grandi et al. (2018). Service providers, who are black skin color, are considered less attractive than those who have a white skin color. The authors believe that black-andwhite racial disorder is due to mismatch of interest, racial stereotypes, and that more emotional work is needed in order to reduce this coincidence. A study conducted in the study confirmed that the warmth and occupation of people is lower in black people than in white service providers.

Public service agencies and their impact, lessons on theory, politics and practice were explored by Jennifer E. Mosley and Steven Ratgeb Smith (2018). In conclusion, the authors point out that, in terms of people, it is necessary to know more about how the impacts affect four specific and specific groups: service users, larger marginalized communities in which they are embedded, an increasingly insecure human workforce, and the services to people. They also say that it is necessary to increase knowledge about how the impact on influence affects the structural conditions that trigger inequality and needs.

Lejla Aga Kasiri et al. (2017) studied the integration of standardization and adaptation, ie their impact on service quality, customer satisfaction and loyalty. The study was conducted in Malaysia, analyzing the experiences and perceptions of consumers in three service organizations: catering (hotel), health care (hospital) and education (university). The research shows that integration of standardization and adaptation is crucial if the quality of the service has to be improved, then standardization has a greater impact on the quality of service than adjustment, that functional quality has a greater impact on customer satisfaction when comparing it with technical quality and that user satisfaction significant impact on consumer loyalty.

Hana Medler-Liraz and Tali Seger-Gutman (2015) investigated the relationship between strategies of emotional work, the hospitality of the service provider and the quality of service. The paper suggests that emotional work strategies differently reflect on negative emotions provided by service providers during interaction. Showing hostile emotions by service providers is expected to affect perceptions of consumers about the quality of service. On the other hand, the hostile relationship, by the service provider, was negatively linked to the customer's quality assessment.

The complex role of complexity and the answer to the question of how service providers can reduce the negative impact on the perception of the complexity of the service when the sale of professional services was requested by Sven Mikolon et al. (2015). The results of the survey show that the ability of service providers to adapt to the specific nature of the meeting helps users to preserve cognitive capacity. This study highlights the role of perceived complexity of services and determines the importance of clients' cognitive abilities.

The effect of service providers on 


\section{Intermationall Qualilty Conference}

$\mathrm{R} U \mathbf{A} \square \mathrm{IT}$ RIESIEAIRCI-

competitive market positions among fixedprice customers is the name of the work of authors Sabine Moser et al. (2018). The authors believe that fixed prices have a negative effect on users' loyalty, where they believe managers should manage users who proactively show high fixed biases, offering them to switch to tariffs where they pay depending on usage or maybe offer them more expensive lump-sum offerings.

Authors Evangelos L. Somas and Carmen Jaca (2016) investigated the impact of total quality management, more precisely its factors, on the performance of service companies. According to the research, the factors that describe the implementation of total quality management in service companies are concerned with the quality of top management, quality management of employees, management process, knowledge and education of employees, and focus on users.

Explanation of the intermediary role of the quality of services between the persons who deal with quality management and students' satisfaction in higher education institutions: management perception, the topic dealt with by Ehsan Sadeh and Mansur Garkaz (2015). As the authors state, students are truly genuine users of services in higher education institutions, especially in private, where they pay a certain amount of money for their service.

The method based on the so-called. fuzzy SERVQUAL, based on the assessment of the quality of services in the hotel industry, is the title of the work of Stefano, N. M. etc. (2015). The survey shows that the services have a lot of gaps to be filled in, that is, defects that need to be addressed. Also, it is evident that the perceived quality of the service provided is in many segments lower than the expected quality of the service. The study showed that it is particularly important for service companies to monitor the quality of meeting customer needs and requirements, creating competitive advantages.
Luyun Su et al. (2015) explored Chinese tourism, where emphasis was placed on the effects of perceived quality of services on the intentions of shopping and the subjective well-being of Chinese tourists. Authors emphasize that the process of creating stronger relationships with customers can begin by collecting and tracking buying information, and using them to offer some financial incentives. The above stated, of course, strictly does not imply lower prices, but e.g. rewards customers for higher purchases or the introduction or implementation of some loyalty programs.

The relationship between the quality of service, satisfaction, trust, value, commitment and loyalty of Internet service users is a matter that was discussed by the authors Paramaport Taichon and Tu Nian Kwach (2015). The results of the survey show that the quality of the service is closely linked to the trust of clients. It suggests that if service providers provide a high level of overall quality of service, users will show confidence to that particular provider and believe that the company is authentic. Also, the overall quality of the service is a significant factor of consumer commitment.

The strategic framework of fitness clubs, based on quality dimensions, was studied by Elsa Regina Monteiro Vieira and Hoa Hose Fereira (2017). The results of the survey show that competencies, capacities, basic and complementary services are key factors in the strategy of fitness clubs. The authors emphasize that most fitness clubs, which are taken into consideration during the research, attaches great importance to all the above mentioned key factors, regardless of the price and variety of services they provide to clients. The strategic framework shows that fitness clubs generally do not have a defined strategy, nor do they adapt the quality of service to sales prices.

The suggestions and consequences of employees' commitment to service systems, related to the quality of service, were studied by Eise Banu Elmadag et al. (2016). The 
results of the research show that managerial teaching has the strongest impact on the commitment of employees, ie service providers, quality of service, and that employee commitment improves job-related outcomes. The authors suggest that more attention needs to be paid to educating and improving supervisors and managers, in order to better manage their employees, and to more effectively teach them how to do their best work.

The influence of the real failure of the service provider to satisfy the aggregator, a theme taught by Svagato Čaterje (2017). The results show that people believe that the failure of service providers is the responsibility of the organization. Also, if serious efforts are made to tackle failures, the expectations of consumers are likely to be reversed.

The contribution of products and the quality of service providers to the quality of the mobile phone industry was studied by Rebecca A. Scott and so on. (2017). The results of the research show that the organization will benefit greatly if the quality of managerial practice is dedicated, which is based on the product and factors of the service provider.

The assessment of the quality parameters of hospital services, from the perspective of patients, doctors and employees, is the name of the work of the authors, Ajvindera Sing and others. (2018). Providing an effective hospital service and understanding perceptions of all stakeholders, patients, doctors and employees has become a key parameter for the success of each health center, authors point out. The satisfaction of patients requires better synchronization of what patients expect and what management provides. Expectedly, the results show that there is a big difference between the perception of the quality of the provider and the recipient of services. Health organizations must keep in mind that the survival and profitability of the centers is largely dependent on their ability to conquer and attract new patients, the authors point out.

\section{Conclusion}

As we can see, based on analyzed scientific papers, in the field of service systems, health, education, transport, tourism, hotel industry, etc. the quality of the service provided depends on a number of factors, and in particular from the service provider itself. Certainly, the quality of the service provider has many indicators that directly or indirectly affect him, and who can, with lesser or greater success, be controlled.

Commitment, emotional work, skills, knowledge and abilities are just some of the factors of service providers that can lead to consumer satisfaction with service and to their loyalty and trust, which results in the achievement of company goals.

The management of the company needs to work constantly on the development and improvement of its services, putting emphasis on their quality, where real and objectively looking at the situation in the organization, to spot the shortcomings and weaknesses, and to solve them in the best possible way and turn them into the forces, because as Michael Jordan said: "My attitude is that if you push me with something you think is weak, I will turn that anticipated weakness into a force!"

\section{References:}

Topčić, A., Tufekčić, Dž., Cerjaković, E. (2012). Razvoj proizvoda. Univerzitet u Tuzli, Mašinski fakultet u Tuzli.

Simeunović, N., Lalić, B., (2016). Operacioni menadžment. Univerzitet u Novom Sadu. 
Fakultet Tehničkih nauka.

Knežević, J., Tomka, D., Bizjak, B., Fabjan, D., Kukulj, S. (2015). The physical appearance of hotel guests: The impact on service providers' communication and quality service. International Journal of Hospitality Management. (Vol. 5). 8-14.

Dedeoglu, B., B., Demirer, H. (2015). Differences in service quality perceptions of stakeholders in the hotel industry. International Journal of Contemporary Hospitality Management. Available at: http://dx.doi.org/10.1108/IJCHM-08-2013-0350 (17. 01. 2019.).

Ona, J., Ona, R. (2015). Quality of Service in Public Transport Based on Customer Satisfaction Surveys. A Review and Assessment of Methodological Approaches, Transportation Science. Available at: http://dx.doi.org/10.1287/trsc.2014.0544 (18. 01. 2019.).

Choi, K., Lee, D., Olson, D. L. (2013). Service quality and productivity in the U.S. airline industry: a service quality-adjusted DEA model, Springer-Verlag Berlin Heidelberg, doi. 10.1007/s11628-013-0221.

Dhar, R. L. (2014). Service quality and the training of employees: The mediating role of organizational commitment. Tourism Management. (Vol. 46). 419-430 .

Eboli, L., Mazzulla, G. (2014). Relationship between rail passengers' satisfaction and service quality: a framework for identifying key service factors. Springer-Verlag Berlin Heidelberg. doi. 10.1007/s12469-014-0096-X.

Forman, A., M., Thelen, S., Shapiro, T. (2015). Domestic versus offshore service providers. Journal of Service Management. (Vol. 22). 608-624. Issue 4.

Giovanis, A., Athanasopoulou, P., Tsoukatos, E. (2015). The role of service fairness in the service quality - realtionship quality - customer loyalty chain: an empirical study. Journal of Service Theory and Practice. Available at: http://dx.doi.org/10.1108/JSTP-11-2013-0263 (18. 01. 2019.).

Grandey, A. A., Houston, III L., Avery, D. R. (2018). Fake It to Make It? Emotional Labor Reduces the Racial Disparity in Service Performance Judgments. Journal of Management. 130. doi. 10.1177/0149206318757019.

Mosley, J. E., Smith, S. R. (2018). Human service agencies and the question of impact: Lessons for theory, policy and practice. Human Service Organizations: Management, Leadership \& Governance. (Vol. 42:2). 113-122.

Kasiri, L. A., Cheng, K. T. G., Sambasivan, M., Sidin, A. M. (2017). Integration of standardization and customization: Impact on service quality, customer satisfaction and loyalty. Journal of Retailing and Consumer Services. (Vol. 35). 91-97.

Medler-Liraz, H., Seder-Guttmann, T. (2015). The Relationship Between Emotional Labor Strategies, Service Provider Hostility and Service Quality, Service Marketing Quarterly. Available at: http://dx.doi.org/10.1080/15332969.2015.1048655 (20. 01. 2019.).

Mikolon, S., Kolberg, A., Haumann, T., Wieseke, J. (2015). The Complex Role of Complexity: How Service Providers Can Mitigate Negative Effects of Perceived Service Complexity When Selling Professional Services. Journal of Service Research. 1-16. doi. 10.1177/1094670514568778.

Moser, S., Schumann J. H., Wangenheim von F., Uhrich, F., Frank, F. (2018). The Effect of a Service Provider's Competitive Market Position on Churn Among Flat-Rate Customers. Journal of Service Research. 1-17. doi. 10.1177/1094670517752458.

Psomas, E. L., Jaca, C. (2016). The impact of total quality management on service company performance: evidence from Spain. International Journal of Quality \& Reliability Management. (Vol. 33). Issue 3. 380-398.

Sadeh, E., Garkaz, M. (2014). Explaining the mediating role of service quality bteween quality management enablers and students' satisfaction in higher education institutes: the perception 
QUA III II Y

IRIFSIFAIDCI

of managers. Total Quality Management \& Business Excellence. Available at: http://dx.doi.org/10.1080/14783363.2014.931065 (20. 01. 2019.).

Stefano, M. N., Casarotto N. F., Barichello, R., Sohn, P. A. (2015). A fuzzy SERVQUAL based method for evaluated of service quality in the hotel industry. Procedia CIRP 30. 433438.

Su, L., Swanson, R. S., Chen, X. (2016). The effects of perceived service quality on repurchase intentions and subjective well-being of Chinese tourists: The mediating role of relationship quality. Tourism Management. (Vol. 52). 82-95.

Thaichon, P., Quach, N. T. (2015). The relationship between service quality, satisfaction, trust, value, commitment and loyalty of Internet service providers' customers. Journal of Global Scholars of Marketing Science. (Vol. 25:4). 295-313.

Monteiro Vieira R. E., Ferreira, J. J. (2017). Strategic framework of fitness clubs based on quality dimensions: the blue ocean strategy approach. Total Quality Management \& Business Excellence. Available at: http://dx.doi.org/10.1080/14783363.2017.1290523 (20. 01. 2019.).

Elmadag, B. A., Ellinger, E. A., Franke, R. G. (2016). Antecedents and Consequences of Frontline Service Employee Commitment to Service Quality. Journal of Marketing Theory and Practice. (Vol. 16). No 2. 95-110.

Chatterjee, S. (2017). Impact of actual service provider failure on the the satisfaction with aggregator. Journal of Strategic Marketing. Available at: http://dx.doi.org/10.1080/0965254X.2017.1339115 (26. 01. 2019.).

Scott, A. R., Peng, X., Prybutok, R. V. Contribution of Product and Provider Quality to Cell Phone Industry Quality. Quality Management Journal. (Vol. 22:2). 33-47.

Singh, A., Prasher, A., Kaur, N. (2018). Assessment of hospital service quality parameters from patient, doctor and employees' perspectives. Total Quality Management \& Business Excellence. Available at: https://doi.org/10.1080/14783363.2018.1487283 (26. 01. 2019.).

\section{Mirjana Jokanović}

University of East Sarajevo,

Faculty of the Production and

Management Trebinje,

Trebinje,

Bosnia and Herzegovina

mirjana.jokanovic@fpm.ues.rs.ba

\author{
Aleksandra Koprivica \\ University of East Sarajevo, \\ Faculty of the Production and \\ Management Trebinje, \\ Trebinje, \\ Bosnia and Herzegovina \\ aleksandra.koprivica@fpm.ues.rs.ba
}

